\title{
Abatacept Plus Methotrexate Provides Incremental Clinical Benefits Versus Methotrexate Alone in Methotrexate-naive Patients with Early Rheumatoid Arthritis Who Achieve Radiographic Nonprogression
}

\author{
ALVIN F. WELLS, RENE WESTHOVENS, DIANE MONIZ REED, LUCIANA FANTI, JEAN-CLAUDE BECKER, \\ ALLISON COVUCCI, and EDWARD C. KEYSTONE
}

ABSTRACT. Objective. This article reports 1-year clinical outcomes in the subgroup of patients with rheumatoid arthritis in the Abatacept study to Gauge Remission and joint damage progression in methotrexate-naive patients with Early Erosive rheumatoid arthritis (AGREE) who achieved radiographic nonprogression at the end of the double-blind phase.

Methods. Patients who achieved radiographic nonprogression (change from baseline in total Sharp score $\leq 0$ at 12 months) with abatacept plus methotrexate (MTX) or MTX alone were eligible for this analysis. Clinical outcomes were remission, defined by 28-joint Disease Activity Score (DAS28) using C-reactive protein (CRP), low Disease Activity Score (LDAS), American College of Rheumatology (ACR) scores, physical function (Health Assessment Questionnaire), and tender and swollen joint counts. Safety was assessed at each visit.

Results. Patients in the abatacept plus MTX and MTX monotherapy groups had similar baseline characteristics and were similar to the overall study population. The proportion of patients who achieved DAS28 (CRP) remission or LDAS was greater with abatacept plus MTX vs MTX alone [43.2\% vs $22.7 \%(\mathrm{p}<0.001)$ and $57.4 \%$ vs $40.6 \%(\mathrm{p}=0.008)$, respectively]. More patients receiving abatacept plus MTX achieved key ACR responses, including major clinical response (27.3\% vs $11.9 \%$; p < 0.001). Safety profiles were similar in both treatment groups.

Conclusion. More MTX-naive patients with early RA who achieved radiographic nonprogression taking abatacept plus MTX also achieved DAS28 (CRP)-defined remission and LDAS compared with patients who received MTX alone, supporting the use of abatacept as a first-line biologic in combination with disease-modifying antirheumatic drugs. (First Release Sept 1 2011; J Rheumatol 2011;38: 2362-8; doi:10.3899/jrheum.110054)

\section{Key Indexing Terms: RHEUMATOID ARTHRITIS CLINICAL OUTCOMES}

REMISSION

\section{RADIOGRAPHIC NONPROGRESSION ABATACEPT METHOTREXATE}

Rheumatoid arthritis (RA) is a chronic autoimmune disease often characterized by progressive joint damage, which leads to increasing disability over time ${ }^{1,2,3}$. Joint damage occurs early in RA; up to $60 \%$ of patients have joint erosions within 1 year of disease onset. In some patients, structural damage may precede the onset of clinical symptoms ${ }^{4,5,6}$. The presence of prognostic indicators, such as rheumatoid factor (RF) and

From the Medicine, Rheumatology and Immunotherapy Center, Oak Creek, Wisconsin, USA; Department of Rheumatology, UZ KU Leuven, Leuven, Belgium; Bristol-Myers Squibb Global Development and Medical Affairs, Princeton, New Jersey, USA; and Department of Medicine, Division of Rheumatology, University of Toronto, Toronto, Ontario, Canada.

Supported by Bristol-Myers Squibb, Princeton, New Jersey, USA. Dr. Wells is a consultant for Abbott Laboratories, Bristol-Myers Squibb, Genentech Inc., Pfizer, and UCB. Dr. Westhovens is a consultant and/or has participated in speakers' bureaus for Bristol-Myers Squibb, Centocor, and Roche. Dr. Keystone has received research funding, consulted, served on advisory boards, and/or received speaker honoraria from Abbott Laboratories, Amgen Inc., AstraZeneca Pharmaceuticals LP, Biotest, Bristol-Myers Squibb, Centocor, Inc., F. Hoffman-LaRoche Inc., Genentech Inc., Genzyme, Merck, Novartis Pharmaceuticals, Nycomed, anticitrullinated protein antibodies (ACPA) type 2 , is indicative of a poor prognosis for radiographic damage ${ }^{6,7,8}$. Further, greater joint damage at baseline is associated with less improvement in physical functioning after treatment, which highlights the importance of early intervention ${ }^{9,10}$.

Targeted biologic therapies have provided significant benefits compared with traditional RA therapies and represent a

Pfizer Pharmaceuticals, and UCB. Dr. Reed, Dr. Fanti, Dr. Becker, and Ms. Covucci are employees of Bristol-Myers Squibb and hold stock options with the company.

A.F. Wells, MD, PhD, Medicine, Rheumatology and Immunotherapy Center; R. Westhovens, MD, PhD, Department of Rheumatology, UZ KU Leuven; D.M. Reed, PharmD; L. Fanti, MD; J-C. Becker, MD; A. Covucci, MSc, Bristol-Myers Squibb Global Development and Medical Affairs; E.C. Keystone, MD, FRCP, Department of Medicine, Division of Rheumatology, University of Toronto.

Address correspondence to Dr. A.F. Wells, Rheumatology and Immunotherapy Center, 200 East Ryan Road, Suite 101, Oak Creek, WI 53154,USA.E-mail: a.f.wells@att.net

Full Release Article. For details see Reprints/Permissions at jrheum.org Accepted for publication June 24, 2011. 
considerable advancement in the treatment of RA. Increasing evidence from clinical trials in patients with moderate to severe RA suggests that the introduction of biologics in combination with nonbiologics earlier in the course of disease leads to greater clinical benefit in the treatment of early $\mathrm{RA}^{11,12,13,14,15}$. While an association between radiographic damage and loss of physical function over the longterm course of RA has been recognized ${ }^{1,16,17,18,19}$, the relationships among early treatment (particularly in patients with a poor prognosis), radiographic damage, disease activity, and functionality in early disease remain to be established ${ }^{6}$. Data suggest that treatment with a biologic plus methotrexate (MTX) provided greater radiographic inhibition than MTX monotherapy in patients with minimal clinical response, suggesting that clinical measures of RA disease activity and radiographic damage may be dissociated ${ }^{20,21}$.

Abatacept is a soluble human recombinant fusion protein that blocks the activation of $\mathrm{T}$ cells by modulating the CD80/CD86:CD28 costimulatory signal22,23. The sustained clinical $24,25,26$ and radiographic ${ }^{27,28}$ efficacy and consistent safety ${ }^{24,25,26}$ of abatacept in clinical trials of patients with moderate to severe RA who have had an inadequate response to MTX or anti-tumor necrosis factor (TNF) agents have been previously reported. Further, based on data from the recent ADJUST trial, Emery, et al concluded that compared with no treatment, abatacept may delay the progression of undifferentiated or very early RA in a subset of patients with poor prognosis ${ }^{29}$.

The Abatacept study to Gauge Remission and joint damage progression in methotrexate-naive patients with Early Erosive rheumatoid arthritis (AGREE) showed that abatacept plus MTX was more effective than MTX alone in achieving 28-joint Disease Activity Score [DAS28 C-reactive protein (CRP)]-defined remission and inhibiting radiographic progression in an MTX-naive population with early erosive RA and poor prognostic factors ${ }^{15}$. Studies on populations with early RA have shown that combination therapy with biologics and disease-modifying antirheumatic drugs (DMARD) is better than nonbiologic DMARD monotherapy, and a radiographic component may play a role in efficacy $12,13,14,15,30,31$. However, while statistically significant, the clinical significance of radiographic improvements is still unclear.

The AGREE trial provides further opportunity to determine differential or incremental clinical benefits associated with biologic therapy compared with MTX monotherapy among patients with early RA who achieved a similar radiographic outcome.

\section{MATERIALS AND METHODS}

This is a posthoc analysis of data from AGREE. AGREE was a multinational randomized double-blind 2-year study examining abatacept plus MTX compared with MTX monotherapy in MTX-naive patients with both early erosive RA and poor prognostic factors ${ }^{15}$.

Patients. The study design of AGREE has been described ${ }^{15}$. Patients enrolled in AGREE had disease duration $\leq 2$ years, were seropositive for RF and/or
ACPA, and had radiographic evidence of bone erosions. Patients were either MTX-naive at study entry or had previous exposure of $\leq 10 \mathrm{mg} /$ week for 3 weeks but not within 3 months prior to initiation of the study.

Patients were randomized $1: 1$ to receive abatacept $(\approx 10 \mathrm{mg} / \mathrm{kg}$ according to weight range) plus MTX or placebo plus MTX for 1 year (Figure 1). Abatacept was administered according to weight range by intravenous infusion on Days 1, 15, and 29, and every 4 weeks thereafter. MTX was initially dosed at $7.5 \mathrm{mg} /$ week and titrated to $20 \mathrm{mg}$ at Week 8 , where it was maintained. MTX dose reduction to a minimum of $15 \mathrm{mg} /$ week was permitted in cases of toxicity or intolerability.

Stable, fixed low-dose oral corticosteroids (prednisone $\leq 10 \mathrm{mg}$ or equivalent per day) were permitted throughout the study, and up to 2 corticosteroid pulses (prednisone $>10 \mathrm{mg}$ or equivalent oral or injectable corticosteroids for at least 3 consecutive days) during any 6 -month period were permitted. After 6 months, the addition of 1 nonbiologic DMARD was also allowed.

Patients who received at least 1 dose of study medication and achieved radiographic nonprogression, defined as a change from baseline in the Genant-modified total Sharp score (TSS) $\leq 0$ at 1 year, were eligible for this posthoc analysis.

Clinical and safety assessments. Clinical and functional endpoints for this analysis included remission, defined as DAS28 (CRP) $<2.6^{32}$; low Disease Activity Score (LDAS), defined as DAS28 (CRP) $\leq 3.2$; American College of Rheumatology (ACR) 50, 70, and 90 responses; major clinical response (MCR; defined as ACR 70 maintained for $\geq 6$ consecutive months); physical function assessed using the Health Assessment Questionnaire Disability Index (HAQ-DI) ${ }^{33}$; and the number of tender and swollen joints using 68- and 66-joint count assessments, respectively. Safety assessments, including all reported adverse events (AE), serious AE (SAE), and infections, were performed monthly at each scheduled visit and reported for all patients who received at least 1 dose of abatacept.

Statistical analyses. Baseline demographic and disease characteristics were reported using descriptive statistics. Analyses of clinical, functional, and safety outcomes were performed on patients who achieved radiographic nonprogression using data available at the 1-year visit. ACR response, DAS28 remission, and LDAS were assessed using an intent-to-treat population, with patients who discontinued considered nonresponders subsequent to discontinuation for clinical outcomes. Missing radiographic data at Day 365 for discontinued patients were imputed using linear extrapolation. All other analysis was based on as-observed data. A chi-square test corrected for continuity was used to evaluate differences between treatment groups in DAS28 (CRP), MCR, and ACR responses. All confidence intervals were 2-sided.

\section{RESULTS}

Patient disposition and demographics. In the 1-year double-blind portion of AGREE, 509 patients were randomized and treated with abatacept plus MTX or MTX alone. Of the 509 patients, 484 had radiographs collected at baseline and at least 1 post-baseline visit. Sixty-one percent (148 of 242) of patients in the abatacept plus MTX group and 53\% (128 of 242) of patients in the MTX monotherapy group achieved radiographic nonprogression at 1 year and thus were eligible for this analysis. Baseline demographics and disease characteristics were similar between both groups of radiographic nonprogressors (Table 1) and were generally similar to those reported for the overall study population ${ }^{15}$. Mean disease duration was 5.9 and 7.0 months for the abatacept plus MTX and MTX monotherapy groups, respectively. Tender and swollen joint counts were similar between the 2 groups. The mean DAS28 (CRP) was 6.2 in both groups, and mean TSS was 6.7 and 5.8 for the abatacept plus MTX and MTX monotherapy groups, respectively.

Personal non-commercial use only. The Journal of Rheumatology Copyright @ 2011 . All rights reserved. 


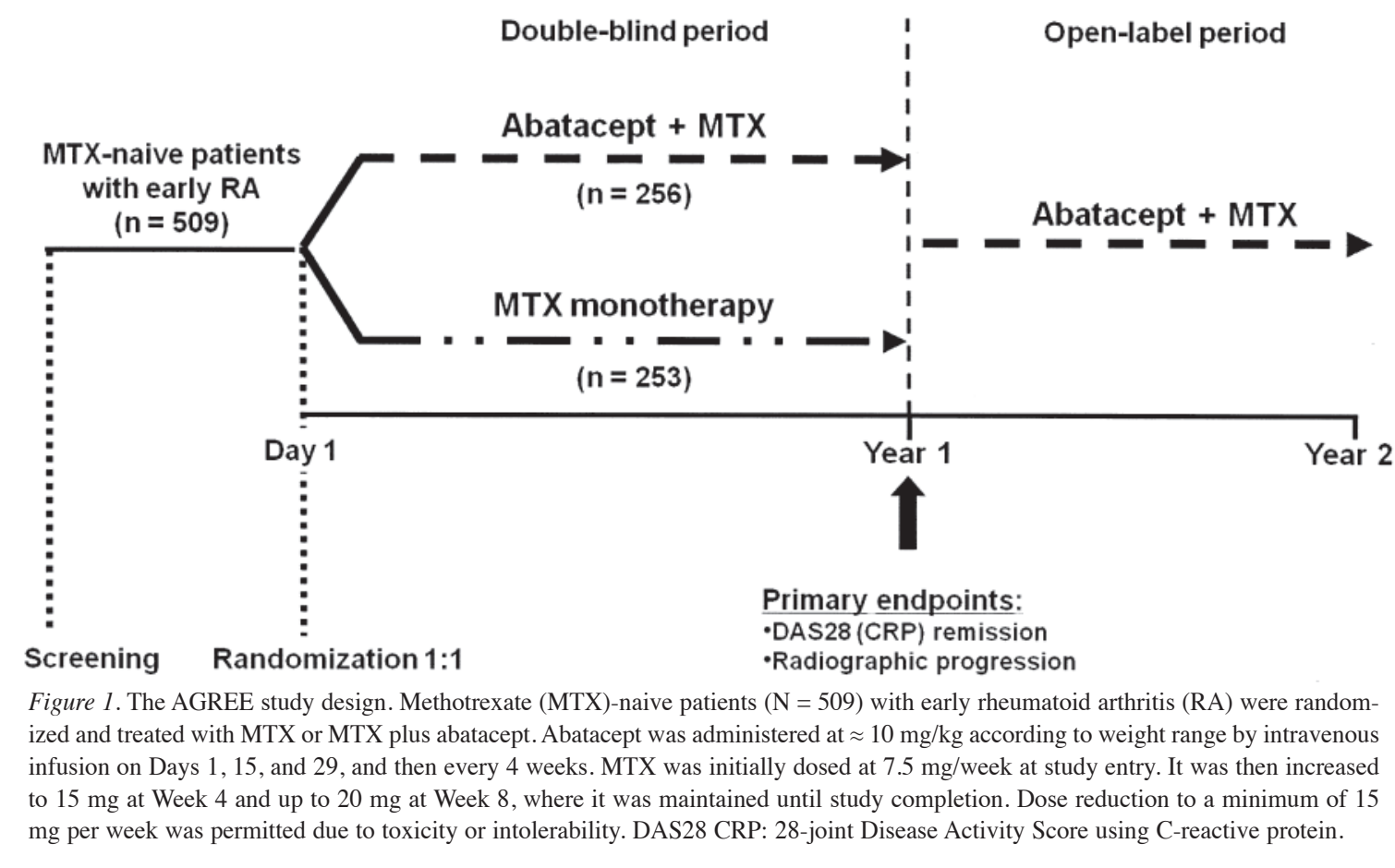

Table 1. Baseline demographic and clinical characteristics of radiographic nonprogressors from AGREE.

\begin{tabular}{lcc}
\hline Characteristic & $\begin{array}{c}\text { Abatacept }+ \text { MTX, } \\
\mathrm{n}=148\end{array}$ & $\begin{array}{c}\text { MTX, } \\
\mathrm{n}=128\end{array}$ \\
\hline Age, mean yrs \pm SD & $49.5 \pm 12$ & $50.2 \pm 13.4$ \\
Female, $\mathrm{n}(\%)$ & $111(75)$ & $106(83)$ \\
Disease duration, mean mo \pm SD & $5.9 \pm 7.8$ & $7.0 \pm 7.0$ \\
RF-positive, $\mathrm{n}(\%)$ & $143(97)$ & $123(96)$ \\
ACPA 2-positive, $\mathrm{n}(\%)$ & $132(89)$ & $105(82)$ \\
DAS28 (CRP), mean \pm SD & $6.2 \pm 1.0$ & $6.2 \pm 1.0$ \\
Tender joints, mean \pm SD & $31.3 \pm 14.5$ & $32.0 \pm 14.9$ \\
Swollen joints, mean \pm SD & $22.9 \pm 10.8$ & $22.0 \pm 9.0$ \\
HAQ-DI, mean \pm SD & $1.6 \pm 0.7$ & $1.7 \pm 0.7$ \\
Genant-modified total Sharp score, & & \\
$\quad$ mean \pm SD & $6.7 \pm 9.6$ & $5.8 \pm 8.1$ \\
\hline
\end{tabular}

MTX: methotrexate; RF: rheumatoid factor; ACPA 2: anticitrullinated protein antibodies; DAS28: 28-joint Disease Activity Score; CRP: C-reactive protein; HAQ-DI: Health Assessment Questionnaire Disability Index.

Disease Activity Score. At 1 year, mean (SD) DAS28 (CRP) was $2.9 \pm 1.29$ and $3.61 \pm 1.29$ for radiographic nonprogressors treated with abatacept plus MTX and MTX alone, respectively. Additionally, more abatacept plus MTX nonprogressors achieved DAS28 (CRP)-defined remission compared with nonprogressors treated with MTX alone $(43.2 \%$ vs $22.7 \%$, respectively; $\mathrm{p}<0.001$; Figure 2). A greater proportion of radiographic nonprogressors treated with abatacept plus MTX also achieved LDAS at 1 year compared with those treated with MTX alone $(57.4 \%$ vs $40.6 \%$, respectively; $\mathrm{p}=$ 0.008 ; Figure 2). The proportion of radiographic nonprogressors achieving DAS28 (CRP) remission increased consistent- ly over time (Figure 3A). The same trend was observed for LDAS in radiographic nonprogressors (Figure $3 \mathrm{~B}$ ).

$A C R$ responses. Radiographic nonprogressors treated with abatacept plus MTX achieved ACR 50, 70, and 90 responses at 1 year more than nonprogressors treated with MTX alone $(p=0.014, p=0.003, p=0.004$, respectively; Figure 4). MCR was achieved in more patients treated with abatacept plus MTX compared with MTX alone (29.1\% vs $11.7 \%$, respectively; $\mathrm{p}<0.001$; Figure 4).

Functional status. At 1 year, mean HAQ-DI decreases from baseline were similar between the 2 groups of radiographic nonprogressors $(-1.0 \pm 0.8$ vs $-0.8 \pm 0.7$ units for abatacept plus MTX vs MTX alone, respectively). Mean tender joint count at 1 year was $6.9 \pm 11.7$ for abatacept plus MTX compared with $10.1 \pm 11.8$ for MTX alone. Mean swollen joint count at 1 year was $3.9 \pm 7.3$ for abatacept plus MTX compared with $6.1 \pm 7.8$ for MTX alone.

Safety and tolerability. The type and incidence of AE and SAE were similar between radiographic nonprogressors receiving abatacept plus MTX and those receiving MTX alone (Table 2) and were generally similar to those reported for the overall study population ${ }^{15}$.

\section{DISCUSSION}

The 2010 RA classification criteria issued by the ACR and the European League Against Rheumatism were designed to facilitate the identification of patients with RA earlier during their disease course ${ }^{34}$. By identifying patients earlier in the disease process, it may be possible to use DMARD therapy earlier in order to ameliorate or prevent the damaging effects of $\mathrm{RA}^{34}$.

Personal non-commercial use only. The Journal of Rheumatology Copyright (c) 2011. All rights reserved. 


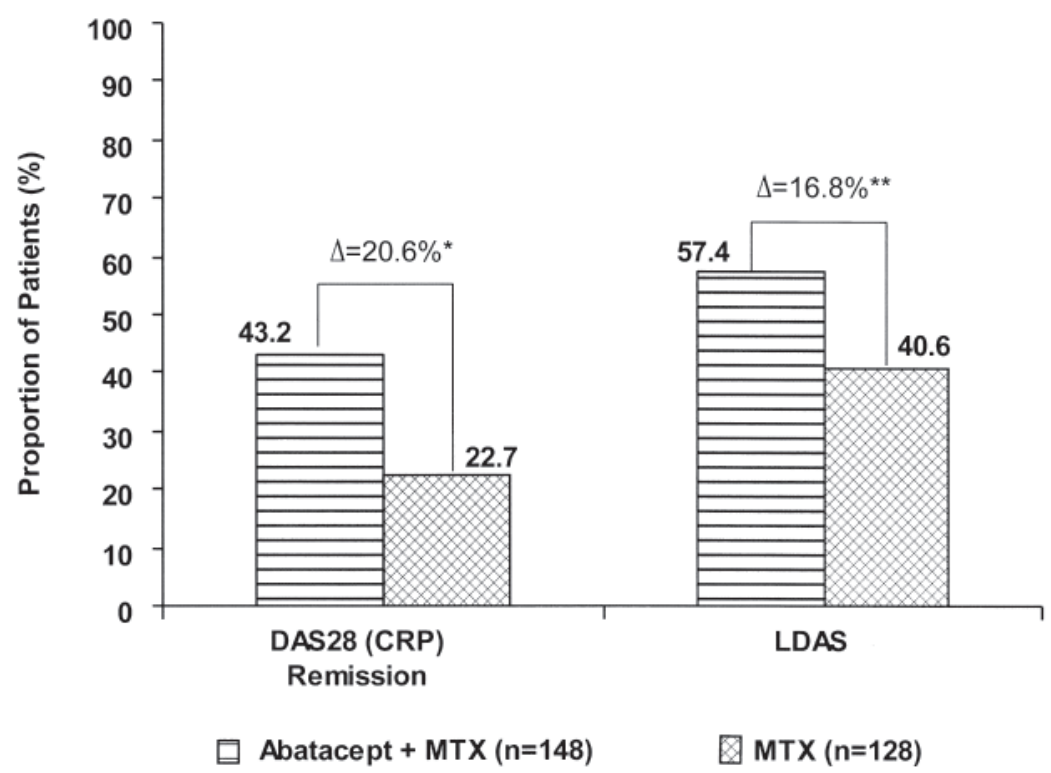

Figure 2. Disease Activity Score using 28 joints (DAS28) outcomes in radiographic nonprogressors at 1 year. After 1 year, a greater proportion of radiographic nonprogressors treated with abatacept plus methotrexate (MTX) achieved DAS28 C-reactive protein (CRP) remission and low DAS (LDAS) compared with nonprogressors treated with MTX alone. *p $<0.001$, $* * \mathrm{p}=0.008$.

In the primary AGREE trial ${ }^{15}$, it was shown that $41.4 \%$ of patients treated with a combination of abatacept and MTX achieved clinical remission (DAS28 < 2.6) compared to $23.3 \%$ of patients in the group that received MTX alone. Further, $61 \%$ of patients treated with abatacept plus MTX achieved radiographic nonprogression $(\mathrm{TSS} \leq 0)$ compared to $53 \%$ of patients treated with MTX alone.

The results of these analyses demonstrate for the first time that despite achieving similar radiographic benefit/nonprogression, MTX-naive patients with early RA with poor prognostic factors treated with abatacept plus MTX achieved greater clinical benefits than those treated with MTX monotherapy. Baseline demographics and disease characteristics were similar between the 2 groups of radiographic nonprogressors. Almost twice as many patients treated with abatacept plus MTX were in clinical remission compared to those receiving MTX alone. Clinical remission was accompanied by improved physical function. In addition, early use of abatacept plus MTX compared with MTX alone resulted in a greater proportion of patients achieving ACR 50, 70, and 90 responses and MCR at 1 year.

The demonstration that only a portion of radiographic nonprogressors achieved clinical remission is consistent with the previously described dissociation between clinical and radiographic outcomes in patients treated with biologics or conventional DMARD ${ }^{20,21,35,36}$. Previous studies of combination therapy with TNF inhibitors and MTX in MTX-naive patients with early RA have shown a higher proportion of patients achieving radiographic nonprogression than those achieving clinical remission $20,21,35,36$. This implies that it is more difficult to achieve clinical remission than radiographic nonprogression, even with intensive early treatment with biologics. To our knowledge, these are the first data to demonstrate this discordance with a biologic agent other than a TNF antagonist. Whether this dissociation reflects a biologic process or the instruments available to define the clinical states remains unclear.

There are inherent limitations to the posthoc analyses presented on the subgroup of patients with radiographic nonprogression. The whole cohort was characterized by radiological nonprogression, to help analyze the differential or incremental clinical benefits offered by combination therapy in these patients. While it is recognized that there has always been variation between the trial setting and the real-world clinical practice setting, these data should be interpreted within the context of this study. While AGREE was not statistically powered to look at outcomes in subgroups, the findings of this posthoc analysis suggest that among MTX-naive patients with early RA in whom radiographic progression is arrested with treatment, there is an incremental clinical benefit when a combination of abatacept plus MTX is used compared with MTX monotherapy. These data further support the early use of intensive combination therapy, such as abatacept and MTX, in patients with early RA, particularly those with features of poor prognosis.

\section{ACKNOWLEDGMENT}

The authors thank Nina Leeds, PhD, Sabrina McGuigan, CMPP, and Anu Santhanagopal, $\mathrm{PhD}$, for editorial and submission assistance. 


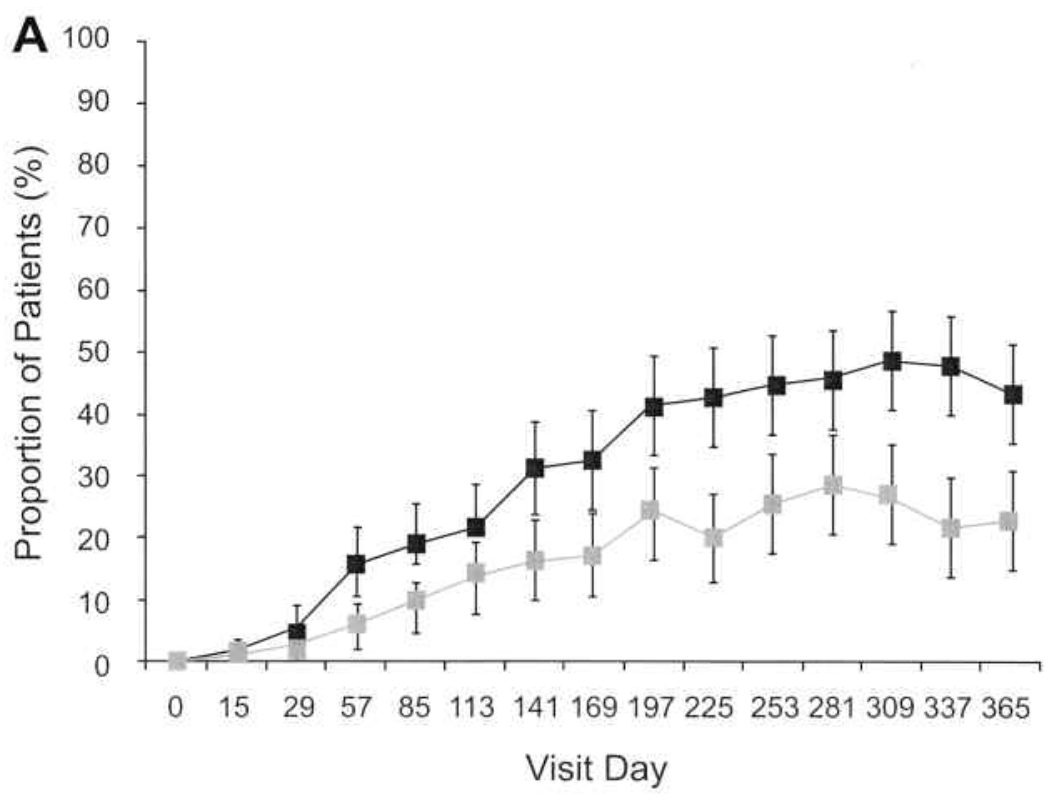

Abatacept $+\operatorname{MTX}(n=148)$

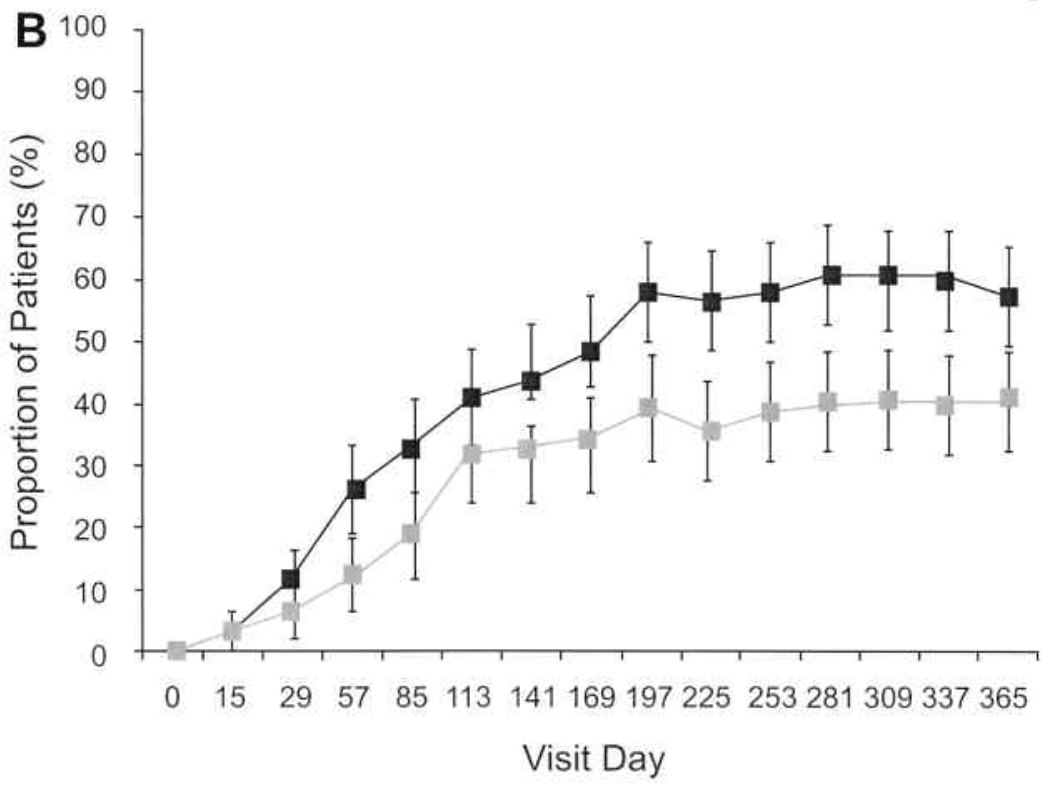

Abatacept $+\operatorname{MTX}(n=148) \quad \operatorname{MTX}(n=128)$

Figure 3. The 28-joint Disease Activity Score using C-reactive protein (DAS28 CRP) remission (A) and low DAS (LDAS; B) in radiographic nonprogressors over 1 year. Over the course of 1 year, the proportion of radiographic nonprogressors achieving DAS28 (CRP) remission or LDAS at any time was greater in patients treated with abatacept plus methotrexate (MTX) vs MTX alone. Error bars represent 95\% CI.

\section{REFERENCES}

1. Scott DL, Pugner K, Kaarela K, Doyle DV, Woolf A, Holmes J, et al. The links between joint damage and disability in rheumatoid arthritis. Rheumatology 2000;39:122-32.

2. Welsing PM, van Gestel AM, Swinkels HL, Kiemeney LA, van Riel PL. The relationship between disease activity, joint destruction, and functional capacity over the course of rheumatoid arthritis. Arthritis Rheum 2001;44:2009-17.

3. Scott DL, Smith C, Kingsley G. Joint damage and disability in rheumatoid arthritis: an updated systematic review. Clin Exp Rheumatol 2003;21 Suppl 31:S20-7.

4. van der Heijde DM. Joint erosions and patients with early rheumatoid arthritis. Br J Rheumatol 1995;34 Suppl 2:74-8.

5. Scott DL. Radiological progression in established rheumatoid 


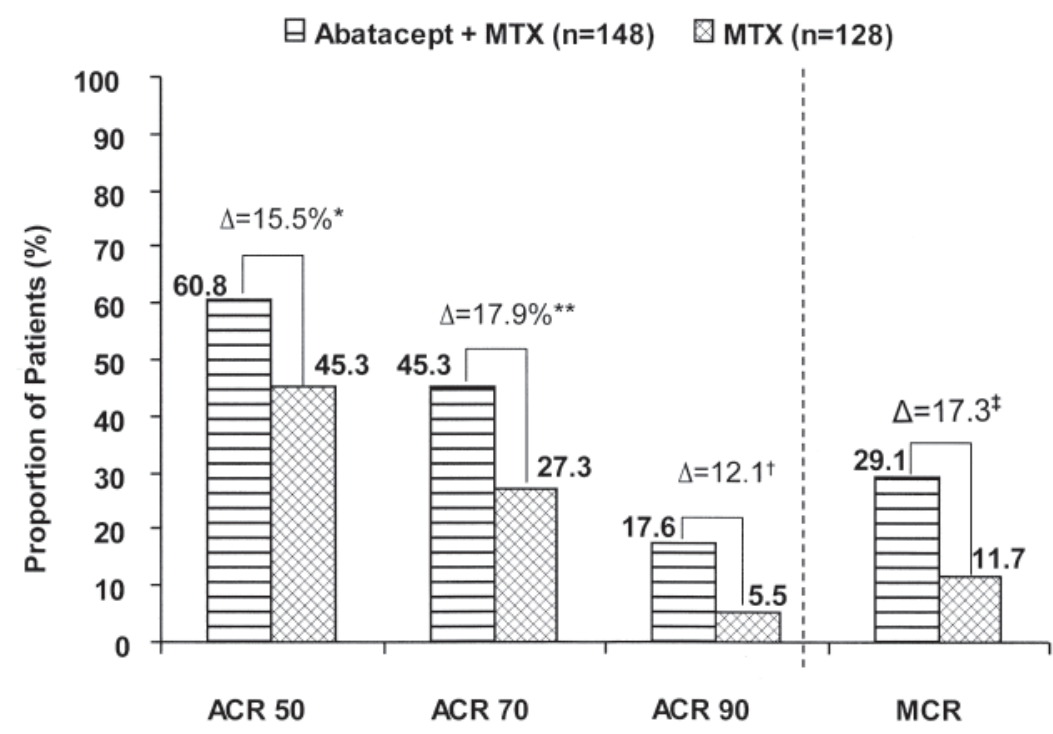

Figure 4. American College of Rheumatology (ACR) responses and major clinical response (MCR) at 1 year among radiographic nonprogressors. A greater proportion of patients treated with abatacept plus methotrexate (MTX) achieved ACR 50, 70, and 90 responses compared with patients treated with MTX alone. MCR was also achieved by a greater proportion of patients treated with abatacept plus MTX compared with patients treated with MTX alone. ${ }^{*} p=0.014$, ** $\mathrm{p}=0.003,{ }^{\dagger} \mathrm{p}=0.004, \stackrel{\dagger}{\dagger} \mathrm{p}<0.001$.

Table 2. Summary of safety in radiographic nonprogressors during 1 year.

\begin{tabular}{lcc}
\hline & \multicolumn{2}{c}{ No. Patients (\%) } \\
& $\begin{array}{c}\text { Abatacept + MTX, } \\
\mathrm{n}=148\end{array}$ & $\mathrm{MTX}$, \\
& $\mathrm{n}=128$ \\
\hline Adverse events (AE) & $130(88)$ & $114(89)$ \\
Discontinuations due to AE & $4(2.7)$ & $7(5.5)$ \\
Infections and infestations & $76(51)$ & $82(64)$ \\
Autoimmune events & $5(3.4)$ & $5(3.9)$ \\
Serious AE & $11(7.4)$ & $10(7.8)$ \\
Discontinuations due to serious AE & $1(0.7)$ & $1(0.8)$ \\
Serious infections and infestations & $2(1.4)$ & $4(3.1)$ \\
Malignancies & $1(0.7)$ & 0 \\
Deaths & $1(0.7)$ & $2(1.6)$ \\
\hline
\end{tabular}

MTX: methotrexate.

arthritis. J Rheumatol Suppl 2004 Mar;69:55-65.

6. Machold KP, Stamm TA, Nell VP, Pflugbeil S, Aletaha D, Steiner

$\mathrm{G}$, et al. Very recent onset rheumatoid arthritis: clinical and serological patient characteristics associated with radiographic progression over the first years of disease. Rheumatology 2007;46:342-9.

7. Kroot EJ, de Jong BA, van Leeuwen MA, Swinkels H, van den Hoogen FH, van 't Hof M, et al. The prognostic value of anti-cyclic citrullinated peptide antibody in patients with recent-onset rheumatoid arthritis. Arthritis Rheum 2000;43:1831-5.

8. Meyer O, Labarre C, Dougados M, Goupille P, Cantagrel A, Dubois A, et al. Anticitrullinated protein/peptide antibody assays in early rheumatoid arthritis for predicting five year radiographic damage. Ann Rheum Dis 2003;62:120-6.

9. Breedveld FC, Han C, Bala M, van der Heijde D, Baker D, Kavanaugh AF, et al. Association between baseline radiographic damage and improvement in physical function after treatment of patients with rheumatoid arthritis. Ann Rheum Dis 2005;64:52-5.

10. van der Heijde D, Landewe R, van Vollenhoven R, Fatenejad S, Klareskog L. Level of radiographic damage and radiographic progression are determinants of physical function: a longitudinal analysis of the TEMPO trial. Ann Rheum Dis 2008;67:1267-70.

11. Emery P, Breedveld FC, Dougados M, Kalden JR, Schiff MH, Smolen JS. Early referral recommendation for newly diagnosed rheumatoid arthritis: evidence based development of a clinical guide. Ann Rheum Dis 2002;61:290-7.

12. St. Clair EW, van der Heijde DM, Smolen JS, Maini RN, Bathon JM, Emery P, et al. Combination of infliximab and methotrexate therapy for early rheumatoid arthritis: a randomized, controlled trial. Arthritis Rheum 2004;50:3432-43.

13. Breedveld FC, Weisman MH, Kavanaugh AF, Cohen SB, Pavelka $\mathrm{K}$, van Vollenhoven R, et al. The PREMIER study: a multicenter, randomized, double-blind clinical trial of combination therapy with adalimumab plus methotrexate versus methotrexate alone or adalimumab alone in patients with early, aggressive rheumatoid arthritis who had not had previous methotrexate treatment. Arthritis Rheum 2006;54:26-37.

14. Emery P, Breedveld FC, Hall S, Durez P, Chang DJ, Robertson D, et al. Comparison of methotrexate monotherapy with a combination of methotrexate and etanercept in active, early, moderate to severe rheumatoid arthritis (COMET): a randomised, double-blind, parallel treatment trial. Lancet 2008;372:375-82.

15. Westhovens R, Robles M, Ximenes AC, Nayiager S, Wollenhaupt $\mathrm{J}$, Durez P, et al. Clinical efficacy and safety of abatacept in methotrexate-naive patients with early rheumatoid arthritis and poor prognostic factors. Ann Rheum Dis 2009;68:1870-7.

16. Drossaers-Bakker KW, de Buck M, van Zeben D, Zwinderman AH, Breedveld FC, Hazes JM. Long-term course and outcome of functional capacity in rheumatoid arthritis: the effect of disease activity and radiologic damage over time. Arthritis Rheum 1999;42:1854-60.

17. Clarke AE, St-Pierre Y, Joseph L, Penrod J, Sibley JT, Haga M, et 
al. Radiographic damage in rheumatoid arthritis correlates with functional disability but not direct medical costs. J Rheumatol 2001;28:2416-24.

18. Drossaers-Bakker KW, Zwinderman AH, Vliet Vlieland TP, Van Zeben D, Vos K, Breedveld FC, et al. Long-term outcome in rheumatoid arthritis: a simple algorithm of baseline parameters can predict radiographic damage, disability, and disease course at 12-year followup. Arthritis Rheum 2002;47:383-90.

19. Maillefert JF, Combe B, Goupille P, Cantagrel A, Dougados M. The 5-yr HAQ-disability is related to the first year's changes in the narrowing, rather than erosion score in patients with recent-onset rheumatoid arthritis. Rheumatology 2004;43:79-84.

20. Emery P, Genovese MC, van Vollenhoven R, Sharp JT, Patra K, Sasso EH. Less radiographic progression with adalimumab plus methotrexate versus methotrexate monotherapy across the spectrum of clinical response in early rheumatoid arthritis. J Rheumatol 2009;36:1429-41

21. Smolen JS, Han C, Bala M, Maini RN, Kalden JR, van der Heijde $\mathrm{D}$, et al. Evidence of radiographic benefit of treatment with infliximab plus methotrexate in rheumatoid arthritis patients who had no clinical improvement: a detailed subanalysis of data from the anti-tumor necrosis factor trial in rheumatoid arthritis with concomitant therapy study. Arthritis Rheum 2005;52:1020-30.

22. Kremer JM, Westhovens R, Leon M, Di Giorgio E, Alten R, Steinfeld $\mathrm{S}$, et al. Treatment of rheumatoid arthritis by selective inhibition of T-cell activation with fusion protein CTLA4Ig. N Engl J Med 2003;349:1907-15.

23. Weisman MH, Durez P, Hallegua D, Aranda R, Becker JC, Nuamah $\mathrm{I}$, et al. Reduction of inflammatory biomarker response by abatacept in treatment of rheumatoid arthritis. J Rheumatol 2006;33:2162-6.

24. Kremer JM, Russell AS, Emery P, Abud-Mendoza C, Szechinski J, Becker JC, et al. Abatacept demonstrates consistent safety and sustained improvements in efficacy through 5 years of treatment in biologic-naive patients with RA [abstract]. Ann Rheum Dis 2009;68:444.

25. Genovese MC, Schiff M, Luggen ME, Le Bars M, Becker JC, Aranda R, et al. Abatacept demonstrates consistent safety and sustained improvements in efficacy through 4 years of open-label treatment in patients with an inadequate response to anti-TNF therapy [abstract]. Arthritis Rheum 2009;60 Suppl 10:1698.

26. Westhovens R, Dougados M, Hall S, Moniz Reed D, Becker JC, Teng J, et al. Disease remission, radiographic non-progression and normalization of function achieved at year 1 are sustained long-term in a majority of patients: 5-year outcomes with abatacept in biologic-naive patients [abstract]. Arthritis Rheum 2009;60 Suppl:1657.
27. Genant HK, Peterfy C, Westhovens R, Becker JC, Vratsanos G, Zhou X, et al. Abatacept increases the proportion of patients who remain free from structural damage progression through 5 years in methotrexate inadequate responders with RA [abstract]. Ann Rheum Dis 2009;68:440.

28. Genovese MC, Schiff M, Luggen M, Becker JC, Aranda R, Teng $\mathrm{J}$, et al. Efficacy and safety of the selective co-stimulation modulator abatacept following 2 years of treatment in patients with rheumatoid arthritis and an inadequate response to anti-tumour necrosis factor therapy. Ann Rheum Dis 2008;67:547-54.

29. Emery P, Durez P, Dougados M, Legerton CW, Becker JC, Vratsanos G, et al. Impact of T-cell costimulation modulation in patients with undifferentiated inflammatory arthritis or very early rheumatoid arthritis: a clinical and imaging study of abatacept (the ADJUST trial). Ann Rheum Dis 2010;69:510-6.

30. Lovinger SP. Use of biologics for rheumatoid arthritis tempered by concerns over safety, cost. JAMA 2003;289:3229-30.

31. Nurmohamed MT, Dijkmans BA. Are biologics more effective than classical disease-modifying antirheumatic drugs? Arthritis Res Ther 2008; 10:118.

32. Wells G, Becker JC, Teng J, Dougados M, Schiff M, Smolen J, et al. Validation of the 28-joint Disease Activity Score (DAS28) and European League Against Rheumatism response criteria based on $\mathrm{C}$-reactive protein against disease progression in patients with rheumatoid arthritis, and comparison with the DAS28 based on erythrocyte sedimentation rate. Ann Rheum Dis 2009;68:954-60.

33. Wells GA, Tugwell P, Kraag GR, Baker PR, Groh J, Redelmeier DA. Minimum important difference between patients with rheumatoid arthritis: the patient's perspective. J Rheumatol 1993;20:557-60.

34. Aletaha D, Neogi T, Silman AJ, Funovits J, Felson DT, Bingham CO 3rd, et al. 2010 rheumatoid arthritis classification criteria: an American College of Rheumatology/European League Against Rheumatism collaborative initiative. Ann Rheum Dis 2010;69:1580-8.

35. Sanmarti R, Gomez-Centeno A, Ercilla G, Larrosa M, Vinas O, Vazquez I, et al. Prognostic factors of radiographic progression in early rheumatoid arthritis: a two year prospective study after a structured therapeutic strategy using DMARDs and very low doses of glucocorticoids. Clin Rheumatol 2007;26:1111-8.

36. Brown AK, Conaghan PG, Karim Z, Quinn MA, Ikeda K, Peterfy $\mathrm{CG}$, et al. An explanation for the apparent dissociation between clinical remission and continued structural deterioration in rheumatoid arthritis. Arthritis Rheum 2008;58:2958-67. 